\title{
Effects of acute and chronic hypercalcemia on parathyroid function and circulating parathyroid hormone molecular forms
}

\author{
Pierre D'Amour \\ University of Montreal, Parathyroid Physiology Laboratory, Centre Hospitalier de l'Université de Montréal-Research Centre, Hôpital Saint-Luc, \\ 264 Rene Levesque Blvd East, Montréal, Québec H2X 1P1, Canada
}

(Correspondence should be addressed to P D’Amour; Email: rechcalcium.chum@ssss.gouv.qc.ca)

Bas et al. (1), in this issue, have demonstrated that acute hypercalcemic clamp over $2 \mathrm{~h}$ in rabbits reduces the subsequent intact (I) parathyroid hormone (PTH) response to hypocalcemia by $50 \%$, while chronic hypercalcemia, secondary to experimental renal failure in the same animal model, fails to reduce the I-PTH response to hypocalcemia. These results raise questions about the acute and chronic influence of calcium concentration on parathyroid function and on circulating PTH molecular forms. To understand and appropriately discuss these differences, it is necessary to review various aspects of PTH physiology.

Circulating PTH is immunoheterogenous. Under normocalcemic conditions, it is composed of $20 \%$ PTH(1-84), the biologically active form of the hormone on the PTH/PTHrP receptor, and of $80 \%$ carboxylterminal (C) fragments, considered until recently to be biologically inactive $(2,3)$. The main circulating $\mathrm{C}$-PTH fragments observed during the peripheral metabolism of ${ }^{125}$ I-bovine (b) PTH( $\left.1-84\right)$ in rats start at positions 34, 37 and 39 (4) of the bPTH structure. Porcine (p) parathyroid cells have been demonstrated to secrete pPTH fragments starting at positions 34 and 37 (5). Studies in humans have also outlined the existence of smaller C-PTH fragments (6) and, more recently, of larger C-PTH fragments with a partially preserved aminoterminal structure (7), called non(1-84)PTH. These non-(1-84)PTH molecular form or forms have been described in humans during the analysis of normal and abnormal serum HPLC profiles using Nichol's I-PTH assay (7), the same assay as that employed by Bas et al. (1) in their study. Most I-PTH assays have since been demonstrated to also react with non-(1-84)PTH (8). Non-(1-84)PTH accounts for $10 \%$ of C-PTH fragments and for $20 \%$ of I-PTH immunoreactivity in normal individuals. It is of particular interest because, on theoretical grounds, it could react with the $\mathrm{PTH} / \mathrm{PTHrP}$ receptor and interfere with the biological effects of PTH(1-84).

Hypercalcemia acutely suppresses PTH secretion to a non-suppressible and detectable PTH concentration (9) while hypocalcemia stimulates PTH secretion to a maximum (9), both stimuli contributing to the sigmoidal relationship between $\mathrm{Ca}^{2+}$ and PTH concentrations (10). $\mathrm{Ca}^{2+}$ concentration also influences PTH secretion qualitatively $(2,3,11,12)$. While suppressing PTH concentration, hypercalcemia favors $\mathrm{C}-\mathrm{PTH}$ fragment secretion over that of $\mathrm{PTH}(1-84)$ (11), C-PTH fragments now accounting for $90 \%$ of circulating PTH immunoheterogeneity, and $\mathrm{PTH}(1-84)$ only $10 \%$, causing a high $\mathrm{C}-\mathrm{PTH} / \mathrm{PTH}(1-84)$ ratio in the circulation $(2,3,12)$. Hypocalcemia stimulates the secretion of $\mathrm{PTH}(1-84)$ more than that of $\mathrm{C}-\mathrm{PTH}$ fragments (11), PTH(1-84) now accounting for 30\% of circulating $\mathrm{PTH}$ immunoheterogeneity, and $\mathrm{C}-\mathrm{PTH}$ fragments $70 \%$, causing a low C-PTH/PTH $(1-84)$ ratio in the circulation $(2,3,12)$. This acute control of PTH secretion and of circulating PTH molecular forms is post-translational $(13-15)$. PTH synthesis always proceeds maximally in the parathyroid glands, and the amount of PTH available for secretion is controlled by a $\mathrm{Ca}^{2+}$-dependent degradation process $(13-15)$ involving destruction of secretory granule content in lysosomes and possibly also within secretory granules (16-18). In rats, the predominance of one type of secretory granule over the other depends on $\mathrm{Ca}^{2+}$ concentration (17). C-PTH fragments are generated and secreted from these processes $(19,20)$. This type of regulation is rapid (13-15) and probably best explains the decrease in mean stimulated I-PTH observed by Bas et al. (1) after hypercalcemic clamp in normal rabbits. Similar results have been observed in cows (21), dogs (22) and humans (23). These modifications are of short duration and can be reversed by a hypocalcemic stimulation that is long enough (23). It is unlikely that other mechanisms are involved in this acute regulation of parathyroid function observed by Bas et al. (1) in view of the short time-course of their experimentation.

The significance of these quantitative and qualitative changes in parathyroid function and circulating PTH molecular forms may arise from two recent studies $(24,25)$ where human (h) $\operatorname{PTH}(7-84)$, and other synthetic C-PTH fragments, to a lesser extent, were found to have biological effects of their own and to antagonize some PTH(1-84) and $\mathrm{PTH}(1-34)$ biological effects. hPTH(7-84) was used in these studies as the only available representative of non-(1-84)PTH, with hPTH(39-84) and (53-84) as representatives of other circulating C-PTH fragments. $\mathrm{hPTH}(7-84)$ was 
used alone or with the other synthetic C-PTH fragments, in a mixture, in an attempt to duplicate the in vivo situation. In both cases, $\mathrm{hPTH}(7-84)$ decreased $\mathrm{Ca}^{2+}$ concentration in thyroparathyroidectomized rats and antagonized the calcemic effect of $\mathrm{PTH}(1-84)$ $(24,25)$ or $\mathrm{PTH}(1-34)(25)$ in the same animals. The $\mathrm{Ca}^{2+}$ level observed during the combined infusion of $\mathrm{PTH}(1-84)$ and $\mathrm{PTH}(7-84)$ was the net result of addition of the positive influence of $\mathrm{PTH}(1-84)$ and of the negative influence of $\mathrm{PTH}(7-84)$. These results suggested that a high $\mathrm{C}-\mathrm{PTH} / \mathrm{PTH}(1-84)$ ratio in the circulation tended to decrease the PTH(1-84) calcemic action, while a low ratio would do the reverse, allowing more rapid and efficient control of calcium concentration in blood. PTH(7-84) was also found to reduce the phosphatemic and phosphaturic influence of PTH(1-84) $(24,25)$ and $\operatorname{PTH}(1-34)(25)$, and to bind to a C-PTH receptor and not to the PTH/PTHrP receptor in ROS 17/2.8 clonal cells, suggesting a mechanism of action through a receptor different from the $\mathrm{PTH} / \mathrm{PTHrP}$ receptor (25). Since C-PTH receptors exist in large quantities on osteocytes (26), we postulated that the rapid anticalcemic effect of $\mathrm{PTH}(7-84)$ could involve the inhibition of osteocytic osteolysis and/or the stimulation of calcium/phosphate accretion into bone. More studies will be required to demonstrate that these results are applicable to endogenous non-(1-84)PTH and other C-PTH fragments, once the exact structure of non-(1-84)PTH is elucidated.

The influence of chronic hypercalcemia on parathyroid function and on circulating PTH molecular forms is more difficult to analyze because one must take into account phosphate and 1,25-dihydroxyvitamin $\mathrm{D}\left(1,25(\mathrm{OH})_{2} \mathrm{D}\right)$ levels which also influence parathyroid function. This is best illustrated by the experimental model chosen by Bas et al. (1), where hypercalcemia was induced in rabbits by chronic renal failure and was accompanied by low circulating levels of $1,25(\mathrm{OH})_{2} \mathrm{D}$ and phosphate. One could also take as an example sarcoidosis where hypercalcemia would be present with high $1,25(\mathrm{OH})_{2} \mathrm{D}$ and phosphate levels (27).

First, one must ask if the influence of acute hypercalcemia on parathyroid function and PTH molecular forms is still present in chronic hypercalcemia. The answer is probably yes. We have demonstrated that patients with non-parathyroid hypercalcemia, while having a mean basal I-PTH level similar to that observed in normal individuals made acutely hypercalcemic, had a more elevated C-PTH level and a higher C-PTH/I-PTH ratio (28). We have also demonstrated, in various chronic experimental models associated with a need for higher PTH levels (secondary hyperparathyroidism, half parathyroidectomy) or lower PTH levels (treatment of secondary hyperparathyroidism, $1,25(\mathrm{OH})_{2} \mathrm{D}$ administration), further adaptation of the C-PTH/PTH(1-84) ratio to hypo- and hypercalcemia compared with acute experiments. A chronic need for higher PTH levels was associated with a further decrease in the C-PTH/PTH(1-84) ratio at all $\mathrm{Ca}^{2+}$ concentrations while a chronic need for lower PTH levels was the reverse (29-31), indicating further adaptation of the C-PTH/PTH(1-84) ratio to chronic stimuli, possibly via changes in intracellular PTH degradation. These findings suggest that this type of control still exists with further adaptation in chronic experimental models.

Why was parathyroid function or at least stimulated I-PTH then unchanged with chronic hypercalcemia in the Bas et al. (1) study? This is probably best explained by the net result of several opposing influences exerted either at the transcriptional or post-transcriptional level by calcium, phosphate and $1,25(\mathrm{OH})_{2} \mathrm{D}$ concentrations, with a predominant effect of the latter. Chronic hypercalcemia slightly decreases preproPTH mRNA while hypocalcemia does the reverse (32-37). Chronic hypophosphatemia also decreases preproPTH mRNA while hyperphosphatemia does the reverse (38). Both calcium and phosphate concentrations act post-transcriptionally to stimulate or inhibit the production of proteins which bind to preproPTH mRNA to influence its stability and, thus, its degradation (38). Thus, one would expect preproPTH mRNA to be decreased in the Bas et al. (1) experiment based on $\mathrm{Ca}^{2+}$ and phosphate concentrations but, obviously, this is probably not the case because of the dominant influence of low $1,25(\mathrm{OH})_{2}$ level on PTH gene transcription $(39,40)$, preproPTH mRNA level (41) and PTH secretion (42). Several clinical situations can be used to illustrate the point. Treatment with $1,25(\mathrm{OH})_{2} \mathrm{D}$ in patients with renal failure decreases basal and stimulated I-PTH levels even if hyperphosphatemia is present (43). Stopping $1,25(\mathrm{OH})_{2} \mathrm{D}$ therapy in patients with renal failure increases PTH levels to high pretreatment values (44). In a rare case of sarcoidosis in an anephric patient with hypercalcemia, hyperphosphatemia, low PTH and high $1,25(\mathrm{OH})_{2} \mathrm{D}$ concentrations, treatment with cortisone led to decreased $1,25(\mathrm{OH})_{2} \mathrm{D}$ and higher PTH levels (45). Finally, in a patient with severe primary hyperparathyroidism and osteitis fibrosa cystica, $1,25(\mathrm{OH})_{2} \mathrm{D}$ concentration in serum was demonstrated to be low to start with in relation to the severe hypercalcemia (46). Treatment with i.v. bisphosphonate and vitamin D supplementation prior to surgery reduced $\mathrm{Ca}^{2+}$ concentration to a near normal level but with very high $1,25(\mathrm{OH})_{2} \mathrm{D}$ concentration and I-PTH and C-PTH levels half of what they were prior to treatment, even if the $\mathrm{Ca}^{2+}$ level had decreased (46). All this illustrates that the $1,25(\mathrm{OH})_{2} \mathrm{D}$ transcriptional influence on the PTH gene is probably dominant over the post-transcriptional role of calcium or phosphate concentration. In fact, in the model of Bas et al. (1), if the transcriptional influence of $1,25(\mathrm{OH})_{2} \mathrm{D}$ is sufficiently important, all other post-transcriptional and 
post-translational controls could be present and effective, and the net result could still be a normal stimulated I-PTH level. Correction of the $1,25(\mathrm{OH})_{2} \mathrm{D}$ level in rabbits with chronic renal failure to the value observed in normal rabbits through supplementation would probably have permitted better appreciation of other levels of PTH function regulation in this experimental model.

Overall, the paper of Bas et al. (1) illustrates the complexity of the acute and chronic regulation of parathyroid function in vivo and raises the question of the priority of a given stimulus over others in this regulation, leaving room for further experimentation.

\section{References}

1 Bas S, Aguilera-Tejero E, Estepa JC, Garfia B, Lopez I \& Rodriguez M. The influence of acute and chronic hypercalcemia on the parathyroid hormone response to hypocalcemia in rabbits. European Journal of Endocrinology 2001146 411-418.

2 D'Amour P, Labelle F, Lecavalier L, Plourde V \& Harvey D. Influence of serum $\mathrm{Ca}$ concentration on circulating molecular forms of PTH in three species. American Journal of Physiology (Endocrinology and Metabolism) 1986251 E680-E687.

3 D’Amour P, Palardy J, Bashali G, Malette LE, DeLéan A \& Lepage R. Modulation of circulating parathyroid hormone immunoheterogeneity in man by ionized calcium concentration. Journal of Clinical Endocrinology and Metabolism 199275 525-532.

4 D'Amour P, Segre GV, Roth S \& Potts JT Jr. Analysis of parathyroid hormone and its fragments in rat tissues: chemical identification and microscopical localization. Journal of Clinical Investigation $19796389-98$.

5 Morrissey JJ, Hamilton JW, MacGregor RR \& Cohn DV. The secretion of parathyroid fragments $34-84$ and $37-84$ by dispersed porcine parathyroid cells. Endocrinology $1980 \quad \mathbf{1 0 7}$ $164-171$.

6 D'Amour P, Labelle F, Wolde-Ghiorgis R \& Hamel L. Immunological evidences for the presence of small late carboxylterminal fragments(s) of human parathyroid hormone (PTH) in circulation in man. Journal of Immunoassay 198910 191-205.

7 Brossard JH, Cloutier M, Roy L, Lepage R, Gascon-Barre M \& D'Amour P. Accumulation of non-(1-84) molecular form of parathyroid hormone (PTH) detected by intact PTH assay in renal failure: importance in the intepretation of PTH values. Journal of Clinical Endocrinology and Metabolism $1996 \mathbf{8 1}$ 3923-3929.

8 Lepage R, Roy L, Brossard JH, Rousseau L, Dorais C, Lazure C \& D'Amour P. A non-(1-84) circulating parathyroid hormone (PTH) fragment interferes significantly with intact PTH commercial assay measurements in uremic samples. Clinical Chemistry $1998 \mathbf{4 4} 805-809$.

9 Mayer GP, Habener HF \& Potts JT Jr. Parathyroid hormone in vivo. Demonstration of a calcium-independent, non-suppressible component of secretion. Journal of Clinical Investigation $1976 \mathbf{5 7}$ $678-683$.

10 Mayer GP \& Hurst JG. Sigmoidal relationship between parathyroid hormone secretion rate and plasma calcium concentration in calves. Endocrinology 1978102 1036-1042.

11 Mayer GP, Keaton JA, Hurst JG \& Habener JF. Effect of plasma calcium concentration on the relative proportion of hormone and carboxyl fragments in parathyroid venous blood. Endocrinology $19791041778-1784$.

12 Cloutier M, Rousseau L, Gascon-Barré M \& D'Amour P. Immunological evidences for post-translational control of parathyroid function by ionized calcium in dogs. Bone and Mineral 199322 197-207.
13 Chu LLH, MacGregor RR, Anast CS, Hamilton JW \& Cohn DV. Studies on the biosynthesis of rat parathyroid hormone and proparathyroid hormone: adaptation of the parathyroid gland to dietary restriction of calcium. Endocrinology $1973 \quad 93$ 915-924.

14 Habener JF, Kemper B \& Potts JT Jr. Calcium-dependent intracellular degradation of parathyroid hormone: a possible mechanism for regulation of hormone stores. Endocrinology 197597 $431-441$.

15 Morrissey JJ \& Cohn DV. Secretion and degradation of parathormone as a function of intracellular maturation of hormone pools. Journal of Cell Biology 197983 521-528.

16 MacGregor RR \& Bansal DD. Inhibitors of cellular proteolysis cause increased secretion from parathyroid cells. Biochemical and Biophysical Research Communications $19891601339-1343$.

17 Segoguti T, Inoue Y \& Wild P. The biological significance of storage granules in rat parathyroid cells. Microscopy Research and Technique 199532 148-163.

18 Hashizumo Y, Waguri S, Watanabe T, Kominami E \& Uchiyama Y. Cysteine proteinases in rat parathyroid cells with special reference to their correlation with parathyroid hormone (PTH) in storage granules. Journal of Histochemistry and Cytochemistry 199541 $273-282$.

19 Hanley DA \& Axer LM. Calcium-dependent release of carboxylterminal fragments of parathyroid hormone by hyperplastic human parathyroid tissue in vitro. Journal of Clinical Endocrinology and Metabolism 198663 1075-1079.

20 MacGregor RR, Jilka RL \& Hamilton JW. Formation and secretion of fragments of parathormone. Identification of cleavage sites. Journal of Biological Chemistry 1986261 1929-1934.

21 Blum JW, Kunz P, Rodriguez SM \& Fischer JA. Parathyroid hormone response to hypocalcaemia following hypercalcaemia. Acta Endocrinologica $19819675-80$.

22 Sanchez J, Aguilera-Tejero E, Estepa JC, Almaden Y, Rodriguez M \& Felsenfeld AJ. A reduced PTH response to hypocalcemia after a short period of hypercalcemia: a study in dogs. Kidney International 199650 (Suppl 57) S18-S22.

23 Grant FD, Conlin PR \& Brown EM. Rate and concentration dependence of parathyroid hormone dynamics during stepwise changes in serum ionized calcium in normal humans. Journal of Clinical Endocrinology and Metabolism 199071 370-378.

24 Slatopolsky E, Finch J, Clay P, Martin D, Sicard G, Singera G et al. A novel mechanism for skeletal resistance in uremia. Kidney International $2000 \mathbf{5 8} 753-761$.

25 Nguyen-Yamamoto L, Rousseau L, Brossard JH, Lepage R \& D'Amour P. Synthetic carboxylterminal fragments of PTH decrease ionized calcium concentration in rats by acting on a receptor different from the PTH/PTHrP receptor. Endocrinology 2001142 1386-1392.

26 Divieti P, Inomata N, Chapin KR, Singh H, Jüppner H \& Bringhurst FR. Receptors for the carboxyl-terminal region of PTH(1-84) are highly expressed in osteocytic cells. Endocrinology 2001142 916-925.

27 Bell NH. Endocrine complications of sarcoidosis. Endocrinology and Metabolism Clinics of North America 199120 645-654.

28 Brossard JH, Whittom S, Lepage R \& D'Amour P. Carboxylterminal fragments of parathyroid hormone are not secreted preferentially in primary hyperparathyroidism as they are in other causes of hypercalcemia. Journal of Clinical Endocrinology and Metabolism 199377 413-419.

29 Cloutier M, Gascon-Barré M \& D'Amour P. Chronic adaptation of dog parathyroid function to a low calcium, high sodium, vitamin $\mathrm{D}$ deficient diet. Journal of Bone and Mineral Research 19927 1021-1028.

30 Cloutier M, Brossard JH, Gascon-Barré M \& D’Amour P. Lack of involution of hyperplastic parathyroid glands in dogs. Adaptation via a decrease in the calcium stimulation set point and a change in secretion profile. Journal of Bone and Mineral Research 19949 621-629.

31 Cloutier M, Gagnon Y, Brossard JH, Gascon-Barré M \& D’Amour P. Adaptation of parathyroid function to i.v. 1,25-dihydroxyvitamin 
$\mathrm{D}_{3}$ or partial parathyroidectomy in normal dogs. Journal of Endocrinology 1997155 133-141.

32 Heinrich G, Kronenberg HM, Potts JT Jr \& Habener JF. Parathyroid hormone messenger ribonucleic acid: effects of calcium on cellular regulation in vitro. Endocrinology $1983112449-458$.

33 Russell J, Lettieri D \& Sherwood LM. Direct regulation by calcium of cytoplasmic messenger ribonucleic acid coding for pre-proparathyroid hormone in isolated bovine parathyroid cells. Journal of Clinical Investigation $1983 \mathbf{7 2}$ 1851-1855.

34 Brookman J, Farrow SM, Nicholson L, O'Riordan JLH \& Hendy GN. Regulation by calcium of parathyroid hormone mRNA in cultured parathyroid tissue. Journal of Bone and Mineral Research $19861529-537$.

35 Yamamoto M, Igarashi T, Muramatsu M, Fukagawa M, Motokura $\mathrm{T} \&$ Ogata E. Hypocalcemia increases and hypercalcemia decreases the steady-state level of parathyroid hormone messenger RNA in the rat. Journal of Clinical Investigation $1989 \mathbf{8 3}$ 1053-1056.

36 Navey-Many T, Friedlaender MM, Mayer H \& Silver J. Calcium regulates parathyroid hormone messenger ribonucleic acid (mRNA), but not calcitonin mRNA in vivo in the rat. Dominant role of 1,25-dihydroxyvitamin D. Endocrinology $1989 \mathbf{1 2 5}$ 275-280.

37 Naveh-Many T \& Silver J. Regulation of parathyroid hormone gene expression by hypocalcemia, hypercalcemia, and vitamin D in the rat. Journal of Clinical Investigation 199086 1313-1319.

38 Moallem E, Kilav R, Silver J \& Navey-Many T. RNA-protein binding and post-transcriptional regulation of parathyroid hormone gene expression by calcium and phosphate. Journal of Biological Chemistry 1998273 5253-5259.

39 Russell J, Lettieri D \& Sherwood LM. Suppression by $1,25(\mathrm{OH})_{2} \mathrm{D}_{3}$ of transcription of the pre-proparathyroid hormone gene. Endocrinology $19861192864-2866$.

40 Silver J, Naveh-Many T, Mayer H, Schmelzer JH \& Popovtzer MM. Regulation by vitamin D metabolites of parathyroid gene transcription in vivo in the rat. Journal of Clinical Investigation 198678 1296-1301.

41 Silver J, Russell J \& Sherwood LM. Regulation by vitamin D metabolites of messenger ribonucleic acid for preproparathyroid hormone in isolated bovine parathyroid cells. PNAS $1985 \mathbf{8 2}$ $4270-4273$.

42 Cantley LK, Russell J, Lettieri D \& Sherwood LM. 1, 25-Dihydroxyvitamin $\mathrm{D}_{3}$ suppresses parathyroid hormone secretion from bovine parathyroid cells in tissue culture. Endocrinology 1985 $1172214-2219$.

43 Brossard JH, Roy L, Lepage R, Gascon-Barré M \& D'Amour P. Intravenous $1,25(\mathrm{OH})_{2} \mathrm{D}$ therapy increases the intact parathyroid hormone secretion set point in hemodialysed patients. Mineral and Electrolyte Metabolism 199723 25-32.

44 Slatopolsky E, Weerts C, Thielan J. Horst R, Harter H \& Martin KJ. Marked suppression of secondary hyperparathyroidism by intravenous administration of 1,25-dihydroxy-cholecalciferol in uremic patients. Journal of Clinical Investigation $1984 \mathbf{7 4}$ 2136-2143.

45 Barbour GL, Coburn JN, Slatopolsky E, Norman AW \& Horst RL. Hypercalcemia in an anephric patient with sarcoidosis: evidence for extrarenal generation of 1,25-dihydroxyvitamin D. New England Journal of Medicine 1981305 440-443.

46 Brossard JH, Garon J, Lepage R, Gascon-Barré M \& D'Amour P. Inhibition of $1,25(\mathrm{OH})_{2} \mathrm{D}$ production by hypercalcemia in osteitis fibrosa cystica: influence on parathyroid hormone secretion and hungry bone disease. Bone and Mineral 1993 23 15-26.

Received 7 August 2001

Accepted 9 November 2001 